\title{
Housing provision in the Kathmandu Valley: Public agency and private sector initiation
}

The haphazard growth of settlements in the Kathmandu Valley is the result of rapid urbanisation, growing poverty, the high cost of land and construction, and dependence on the traditional practice of owner-built housing. This growth has resulted in huge housing deficits and poor home conditions. The government's implementation of the site and services programme as well as land-pooling projects in the 1970s and 1980s benefitted local landowners, but private-sector developments in the 1990s and 2000 s were only accessible to upper-middle and highincome groups. This has forced the urban poor and economically disadvantaged groups to live in slum and squatter developments. Planned development organisation has been weak in terms of physical layout, the creation of socialisation opportunities and a sense of community, and in achieving a desirable population density. The existing legal and institutional framework is inadequate and ineffective for addressing these issues. To fill the gap between the efforts of the public and private sectors and meet the high demands for housing in the valley, clear-cut policies and planning are required. This must be done in order to link housing supply with demand and to ensure the participation of various public and private-sector agencies in land-development and housing projects that will incorporate the urban poor. Local municipalities should also be equipped for managing local resources, coordinating the agencies involved and monitoring development.

Keywords: housing deficits, Kathmandu Valley, rapid urbanisation, private sector, state interventions 


\section{Introduction}

The Nepalese constitution guarantees the right to adequate housing as one of the fundamental rights of all people. Secure housing contributes to those human activities that bring about the development of a nation. It guides the pattern of urban growth, provides a place of socialisation and recreation, enhances economic sustainability and, above all, represents the socio-cultural identity of individual communities. Homes are material assets and psychosocial symbols of achieved status, affecting how people see themselves and how they are seen by others (Dunn, 2002). They provide a secure space, free from outside surveillance (Dupuis, 1998). Poor housing standards lead to pessimism, passivity, chronic stress and a general state of dissatisfaction (Cohen et al., 2000). Housing is also defined as a consumer good, an investment object and a social good (Garnett et al., 1991). Housing, like food and clothing, is a necessary consumer good because social life is not possible without it. It is a durable investment asset that can be used to earn rental profits. In addition, housing has an effect on people's health, crime, socioeconomic development and national identity. It is a social asset that the government cannot ignore.

Rapid urbanisation and haphazard urban growth, a gradual shift in the economic base from agriculture to service and commerce, and the changing lifestyle of city dwellers have not only created a huge demand for housing, infrastructure provision, and social and emergency services, but have also transformed the form and mode of housing development in the Kathmandu Valley. In response to this, the government of Nepal has been implementing land and housing programs since the 1970s, formulating new legislation, establishing new institutions, and urging the private sector's involvement. Urban contributions to the nation's gross domestic product are at $62 \%$ and are expected to rise to $75 \%$ in the Twelfth National Five-Year Development Plan (2012-2017; National Planning Commission, 2002). As a result, housing standards are presently gaining attention from all sectors. This paper analyses the efforts made by public agencies and the private sector to provide planned housing in the Kathmandu Valley. This is analysed from four perspectives. First, it identifies the numerous factors that led to the huge housing deficit in the Kathmandu Valley. Second, it critically reviews the government-implemented land development and housing programs of the 1970s and 1980s and the private-sector constructed housing of the 1990s and 2000s and then presents the numerous weaknesses that were involved in their planning and implementing processes. Third, it relates these shortcomings to the existing legal and institutional framework to examine the effectiveness of these frameworks. Fourth, it proposes some key strategic recommendations and specific guidelines to mitigate the existing problems as well as to address the future housing needs of the valley.

\section{Factors leading to the housing deficit in the Kathmandu Valley}

The huge housing deficit in the Kathmandu Valley is due to a combination of three factors. First, there have been various phases of transition. Politically speaking, this involved the following: the end of the Rana dynasty in 1951, the restoration of a multiparty system in 1990, the Maoist armed struggle in 1996, the recent people's movement that abolished the monarchy and the peace agreement with the Maoists in 2006. Natural disasters also caused great transition because of the loss of properties and homes, environmental degradation and low socioeconomic development in rural regions. There was a huge population migration into the Kathmandu Valley of people seeking better economic and educational opportunities as well as health, safety and other services. Instead of regulating this trend of urbanisation, successive governments adopted a centralising policy and concentrated development projects within the valley, causing a $6 \%$ annual urban population growth (against the national average of $2.1 \%$ ) and resulting in a valley population of about $30.9 \%$ of the total national urban population. The available developed land, extended infrastructure and constructed housing do not meet the demands of the ever-increasing urban population, growing number of vehicle registrations and haphazard expansion of settlement in the Kathmandu Valley (Figure 1). The following are at least some of the driving forces influencing the dynamic pattern of urban growth in the valley: physical conditions, public service accessibility, economic opportunities, land market, population growth, political situation, and plans and policies (Thapa \& Murayama, 2010).

Second, urban poverty and the increasing gap between rich and poor have constrained the accessibility and affordability of housing. Nepal remains one of the poorest countries in the world, with a per capita income of NPR 20,543 (\$278 in 2003-2004; Central Bureau of Statistics, 2004). According to the Tenth National Five-Year Development Plan, the number of people living at or below the poverty line is 38\%: $23 \%$ in urban areas and $44 \%$ in rural areas. In the capital city of Kathmandu, the urban poor are estimated to represent about $15.1 \%$ of the city's population (Research Triangle Institute, 2001). Disparity in income levels is very high, the bottom $60 \%$ earning only $5.8 \%$ of the national income earnings compared to $85.4 \%$ earned by the top $20 \%$ (Central Bureau of Statistics, 1997). Only $62.5 \%$ of households in the Kathmandu Valley live in their own homes and about $33.1 \%$ of homes are available for rental purposes (Central Bureau of Statistics, 2004). In the case of Kathmandu alone, about 30 to $35 \%$ of the population is living in rental housing (World Conservation Union, 1995 ) and $40 \%$ of these are relatively poor with lower levels of 
services compared to people living in owner-occupied housing (Rabenau, 1990). A study of 24 cases of housing in Kathmandu revealed that up to $95 \%$ of families live in homes with an average of 4.8 rooms and 120 square feet of space (Lumanti Support Group for Shelter and Nepal Water for Health, 2000). Another study found a case in which five daily-wage workers shared one rented room no larger than 10 feet by 11 feet for NPR 500 per month ( $\$ 1=$ NPR 74.50 at present; Prarthana, 2004). Another study found that in Kathmandu the number of households increases by 7,500 every year (Informal Sector Research and Study Centre, 2004).

There were only 17 squatter settlements in the valley in 1985 , and in 2003 that number had increased to 64 (Lumanti Support Group for Shelter, 2003). In a span of 18 years, the squatter population increased from 2,134 to 14,500 , almost a sevenfold increase. Popularly known as landless settlements (Nep. sukumbasi basti), squatter developments have provided housing for around 2,600 families or 14,500 people. More than half of the population of the large squatter development close to the urban centre consists of migrants or the low-income group that was displaced from the city centre when many ground-floor apartments were converted into shops (BackeHansen, 1985). It is believed that there are about 50 slum areas (4,000 people) that have no drinking water, toilets or drainage facilities (Tanaka, 1997). Around $60 \%$ of the squatter housing developments are on public land and the remaining $40 \%$ are within public building such as temples and pubs (Nep. pati). Low-income groups such as part-time workers in carpet factories (about 150,000 full-time and 130,000 part-time workers) (Ministry of Population and Environment, 1999; USAID, 1994) and children working as domestic servants in Kathmandu (nearly 21,000 total, 10\% of whom are under 10 years old and 70\% between 11 and 14 years old; Child Workers in Nepal Concerned Centre, 1999) are highly vulnerable not only because they are living and working in hazardous conditions (lacking habitable spaces inside the house and open spaces and other amenities outside the house) but also due to their labour-intensive jobs, lower levels of education and minimal buying potential.

Third, until recently, construction of a house in Nepal was entirely the responsibility of the individual or family. In such an owner-built informal housing development system, individuals first acquire a plot of land through their own finances and then build a house themselves (Adhikari, 1998). All of the infrastructure required for the land and house will be managed incrementally through cooperation with the neighbours. The dwelling units are built and expanded incrementally over a period of time as both the family size and income increase. More than $90 \%$ of the houses are built in this informal way. Around $65 \%$ of houses in the centre of Kathmandu are made of brick and mud mortar, $64 \%$ have only temporary access for vehicles and 26\% have poor sanitary conditions (Regmi \& Joshi, 1988). Thirty to 35\% of the houses built outside of the compact housing development areas during the

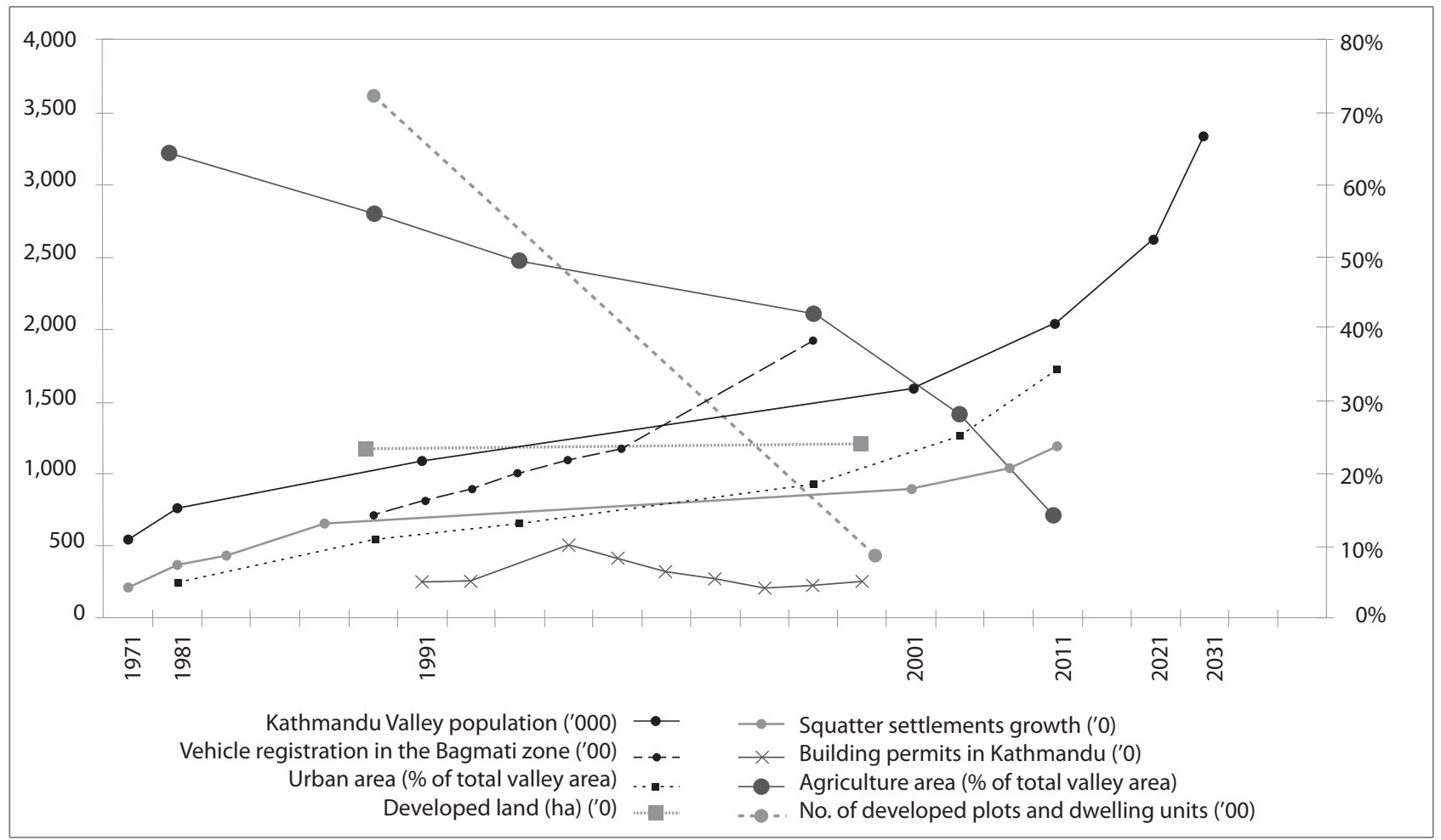

Figure 1: Rapid urbanisation of the Kathmandu Valley and inadequate housing and infrastructure provision (source: Shrestha and Shrestha, 2009). 
last two decades do not have any access roads for emergency vehicles (Ministry of Population and Environment, 1999). Only 25\% of the households in Kathmandu were connected to a sewage system and $17 \%$ of the households had no electricity connection (National Habitat Committee Nepal, 1996). According to the Nepal National Housing Survey from $1991,50.5 \%$ of dwelling units are temporary, $41.2 \%$ are semipermanent and only $8.3 \%$ are permanent housing (Ministry of Housing and Physical Planning, 1996). Increasing slums and squatter housing developments have confirmed the high rate of illegal construction and informal housing development. Inadequately constructed housing with a lack of basic amenities and social services has demonstrated the growing levels of urban poverty in the valley.

These factors had already caused a lack of suitable housing for 242,724 persons in 2001. Taking into account the country's population growth rate in 1991 (3.83\%), the projected population will be 2,357,312 in 2011 and 3,434,100 in 2021. The total number of dwelling units needed in 2021 is projected to be about 435,662 , a figure that represents $15 \%$ of the total population of the valley in 2001 (Kathmandu Valley Town Development Committee, 2000; Table 1). Around 3.3\% of the total population of the valley $(1,645,091$ at present) live below the poverty line of NPR 11,056.80 per person per year (National Planning Commission, 2005). Assuming that the number of urban poor continues to grow at the current rate, an additional 14,376 dwelling units will be required to house 113,325 urban poor in 2021 (Table 1).

\section{The government's site and services programs, land-pooling projects and private-sector initiated housing developments}

The housing sector in Nepal has witnessed a series of trends both in built form and implementation practice over the last few decades from government-subsidised housing production through the site and services programs in the 1970s to landpooling projects (i.e., consolidation, development, and redis- tribution) in the 1980s and private apartment construction in the 2000s. The management of Nepal's efforts towards land development and housing provision can be analysed from three different perspectives showing varying degrees of success and failure. Planned development was initiated in Nepal after the end of the Rana dynasty in 1951, but it was only in 1977, after the enactment of the Town Development Act 1973 (His Majesty's Government, 1973), that the government introduced the concept of the site and services program for the provision of housing for non-gazette level (i.e., low-ranking) civil servants and the general public. Two housing programs were planned during that time: the Kuleswore housing project (on 26.5 ha of land) for civil servants without houses and land in the valley and the Dallu housing project (on $10.8 \mathrm{ha}$ ), which provided housing for the general public. The land required for these projects was acquired through eminent domain. These first programs suffered from reduced influence because of strong resistance from the local landowners due to the low compensation for their lands (the compensation rate of NPR 10,000 per ropani increased to NPR 1,600,000 per ropani (1 ropani $=508 \mathrm{~m}^{2}$ ) after land development), the displacement of those original landowners, poor technical and managerial capabilities on the part of the implementing agency (Kathmandu Valley Town Development Committee), lack of coordination among the various agencies responsible for the timely provisions of physical infrastructures, delays in construction (they were set to be completed in 2 to 3 years but took more than 10 years) and underestimation of the costs considering the long construction delays. The Dallu project had to be converted into a land-pooling project during the 1990 people's movement due to demands by the locals for either release of their lands or compensation at market rate, which was 40 times higher than the government's proposed rate. To meet the housing shortage, the government launched another housing project in 1982 at Galfutar on 14.5 ha of land, which was obtained through compulsory sale. After plotting the land and providing infrastructure to each lot, the government fixed the price at NPR 18,000 per 4 anna plot $\left(127 \mathrm{~m}^{2}\right)$ and gave first priority for buying to the original landowners to prevent their displacement as in the case of the Kuleswore housing project. Only $50 \%$ of the plots were sold in this way and the rest were sold within 3 days through public action.

Table 1: Dwelling units needed to house the projected population in 2021.

\begin{tabular}{lcccc}
\hline Category & $\begin{array}{c}\text { Persons } \\
\text { without housing }\end{array}$ & $\begin{array}{c}\text { Persons per } \\
\text { household }\end{array}$ & $\begin{array}{c}\text { Dwelling units needed } \\
\text { for the urban poor } \\
\text { (below poverty line) }\end{array}$ & $\begin{array}{c}\text { Total number } \\
\text { of dwelling units } \\
\text { needed }\end{array}$ \\
\hline Housing deficit in 2001 & 242,724 & 5 & 1,602 & 48,545 \\
\hline Housing needed 2001-2011 & 739,153 & 5 & 4,878 & 147,831 \\
\hline Housing needed 2011-2021 & $1,076,788$ & 4.5 & 7,896 & 239,286 \\
\hline Total new housing needed in 2021 & & & 14,376 & 435,662 \\
\hline
\end{tabular}

Source: Modified from Kathmandu Valley Town Development Committee (2000). 
Table 2: Completed housing projects in the Kathmandu Valley

\begin{tabular}{lcccccccc}
\hline Project name & $\begin{array}{c}\text { Project area } \\
(\mathrm{ha})\end{array}$ & $\begin{array}{c}\text { Plots } \\
(n)\end{array}$ & $\begin{array}{c}\text { Land- } \\
\text { owners } \\
(n)\end{array}$ & $\begin{array}{c}\text { Implementation } \\
\text { period }\end{array}$ & $\begin{array}{c}\text { Proposed } \\
\text { time } \\
\text { period } \\
\text { (yrs.) }\end{array}$ & $\begin{array}{c}\text { Completed } \\
\text { (yrs.) }\end{array}$ & $\begin{array}{c}\text { Delay } \\
(\text { yrs.) }\end{array}$ & $\begin{array}{c}\text { Implementing } \\
\text { agency }\end{array}$ \\
\hline Sainbu & 22.5 & 760 & 536 & $1991-2003$ & 5 & 12 & 7 & TDC, Lalitpur \\
\hline Dallu & 20 & 691 & 455 & $1991-2003$ & 5 & 12 & 7 & KVTDC, Kathmandu \\
\hline Kamal Vinayak & 7.3 & 205 & 170 & $1991-1996$ & 2 & 5 & 3 & TDC, Bhaktapur \\
\hline Gongabu & 14.4 & 406 & 376 & $1988-1996$ & 4 & 8 & 4 & TDC, Kathmandu \\
\hline Nayabazar & 44.25 & 1,569 & 1,312 & $1995-2003$ & 4 & 8 & 4 & KMC \\
\hline Liwali & 34 & 770 & 667 & $1995-1998$ & 3 & 3 & 0 & Bhaktapur Municipality \\
\hline Gopikrishna & 10.9 & 292 & 242 & $1995-2002$ & 2 & 4 & 2 & TDPIC \\
\hline Sinamangal & 36 & 1070 & 964 & $1995-2003$ & 4 & 8 & 4 & TDPIC \\
\hline Sinchitar & 26.9 & 920 & 812 & $1996-2003$ & 4 & 7 & 3 & TDPIC \\
\hline Lubhu & 13.5 & 243 & 207 & $1993-1996$ & 2 & 3 & 1 & TDPIC \\
\hline Bagmati Corridor & 9.8 & 258 & 239 & $1992-2001$ & 2 & 9 & 7 & TDPIC \\
\hline Total & 239.55 & 7,184 & 5,980 & & & & & \\
\hline
\end{tabular}

Note: KVTDC = Kathmandu Valley Town Development Committee; TDC = Town Development Committee; TDPIC = Town Development Plan Implementation Committee; KMC = Kathmandu Metropolitan City, MPPW = Ministry of Physical Planning and Works.

Source: KVTDC (1999); Department of Urban Development and Building Construction (2003).

On account of the increased resentment of the landowners, the Kathmandu Valley Town Development Committee (KVTDC), after enactment of Town Development Act 1988, implemented another two models of land development based on a participatory approach: Guided Land Development (GLD) and Land Pooling. Under GLD, the access roads were either improved in already existing areas or new access roads were created in previously inaccessible lands through the contributions of the landowners (Ministry of Housing and Physical Planning, 1988). Under the GLD program, $475 \mathrm{~km}$ of roads were to be developed and the progress to date is $300 \mathrm{~km}$. The beneficiaries have donated 170 ha of land, valued at NPR 2,800,000, whereas the government has invested only NPR 70 million in the program (KVTDC, 2002). In the last one and a half decades, the completed 11 land-pooling projects successfully developed about 240 ha of land and provided 7,184 housing units and other plots benefiting 5,980 landowners (1988-2003; Table 2). These completed projects have also contributed 82.27 ha of land in total for roads, open spaces and reserve plots. All of the development costs including infrastructure provision were covered by selling the reserve plots (18.98 ha in total) to the highest bidder.

Because the development costs are not only lower than other types of land development but are also shared by all the landowners, land-pooling projects in the valley are gaining popularity and are the residents' preferred model. The government, without financial burden, was able to produce serviced plots and the landowners, in lieu of contributing some part of their lands, were able to receive regular-sized plots of land with the provision of a vehicular road, open spaces and other amenities in their neighbourhoods. In addition to these, the local real estate and the individual land brokers opened up more than 1,270 ha of land for residential purposes in the municipalities of Kathmandu and Lalitpur between 1971 and 1981 (Halcrow Fox Associates et al., 1991). Their contribution is significant compared to that of the government's efforts. Private owners also supply rental housing that fulfils the housing needs of about $25 \%$ of the total urban population. In the case of the Kathmandu metropolitan area, about $28 \%$ of the city's population lives in rental housing.

In the mid-1990s, the government began to encourage private-sector investment in land and housing development and promulgated the Apartment Ownership Act 1997, which was only finalised in 2003 due to legal and administrative obstacles. Within a span of 2 years (2003-2005), as many as 15 housing companies were sanctioned by the KVTDC for the development of housing units (independent, duplex and apartment types) in the valley. Over a 3-year period, 14 private housing programs produced about 965 dwelling units on 254.3 ropani of land. In response to the public's overwhelming approval of the programme, as many as 150 real estate companies have since registered with the Nepal Land and Housing Development Association. Among them, about 40 to 50 of those companies are registered as Housing Developers and are engaged in various types of developments, each with variation in design, facilities and prices. Some developments are in the planning phase, others are under construction, and still others are in the marketing and sales stage. In 2007, at least 16 apartment buildings and four housing projects were registered for approval in Kathmandu alone. Real estate companies are finding it difficult 
to develop comprehensive housing programs because of the bureaucracy involved: having to go to the Ministry of Population and Environment for environmental impact assessments, the KVTDC for planning permits and the municipality for building permits. Such delays have created uncertainty in the real estate business and high costs of housing units.

Almost all of the private sector housing developments were constructed using reinforced concrete frame structures and had provisions for parking. Electricity and telephone lines were provided by the Nepal Electricity Authority and the Nepal Telecommunication Corporation. Water was pumped from groundwater sources. Depending on the quality of the development and the target groups, other facilities such as swimming pools, gymnasiums, saunas and whirlpool rooms were provided within the housing complexes. User committees were formed to manage solid waste disposal and maintenance of the buildings.

\section{Weaknesses of the planned land developments and housing construction}

The land-development programs initiated by the government and the private-sector housing developments have bolstered the construction industry, raised public awareness regarding planned development and, to some extent, developed the spaces needed to achieve a modern lifestyle. These programs have some weaknesses, however, in terms of planning and implementation. First, the size and scale of the housing programs and land-pooling projects implemented by the public agencies (KVTDC and municipalities) are insufficient to provide for the housing demands in the valley. The public sector built only 8,095 new housing plots (7,184 from land pooling and 911 from site and services provision programs) in the last two and a half decades (1977-2003). The number of annual building permits issued in Kathmandu alone was 3,619 between 1999 and 2001 (Shrestha, 2006). The annual requirement for land is about 409.12 ha only to meet the housing needs in the valley by 2011, but the supply rate is just 15.97 ha annually, projecting a figure of only about 127.76 ha of available land by 2011 (Table 3). Similarly, the supply of housing units in the market is well below the required amount of 24,547 units per year. Fragmented land ownership due to growing demand, shortage in supply, soaring land and construction costs, and inheritance laws have limited comprehensive and consolidated land development (Joshi, 1999).

Second, in all of the land-pooling projects, the master layout, size of urban blocks, infrastructure provisions such as road width and open space requirements including contribution ratios have become site specific and are decided by landowners rather than on an actual-needs basis. The need to maintain self-sufficiency in project finance combined with pressures from the landowners for maximum returns have significantly reduced the scope of the open spaces and community facilities. In fact, planning is limited to conversion of irregular plots into regular ones, with provision for vehicular access to each one. Landowners in the Bagmati Corridor project were ready to participate in the program only after agreeing on the cancellation of the open-space allocation in the original layout. Land planning is not an integrated process, and so the construction of houses and their usage is guided only by individual needs and market conditions. This domination of residential use, with few supporting functions and poor socio-cultural amenities, has made planned neighbourhoods monotonous, sterile and without community life. Moreover, the ad hoc establishment of shops, elementary schools and so on in residential buildings has created another set of problems.

Third, almost all of the residential neighbourhoods implemented by both the public and private sectors are planned in isolation, with little integration of the surrounding, existing areas (Shrestha, 2005). The street networks are not well defined, the urban blocks at Kuleswore are too large and at Gongabu the intersections are inadequate for emergency vehicles (e.g., fire trucks and ambulances) to turn. In the case of the Sun Rise Home, the children's play area was placed between parking lots, under a high-voltage line, in an area unfit for housing units. The gross population density in these housing developments is too low (159 persons per hectare at the Kuleswore housing development and 143 persons per hectare at Gongabu) compared to the minimum gross population density of 300 persons per hectare recommended in the Development Plan for 2020 of the Kathmandu Valley. In the case of private-sector developments, although they have moderate gross-population density values (356 persons per hectare at Sun Rise Home in Lalitpur) and the land division and building construction are integrated processes, the lack of social and religious activities in

Table 3: The gap between the demand and supply of land for housing units

\begin{tabular}{lcccc} 
& \multicolumn{2}{c}{ Annual production } & \multicolumn{2}{c}{ Production by 2011} \\
\cline { 2 - 5 } & Demand & Supply & Demand & Supply \\
\hline Land & 409.12 ha & 15.97 ha & 3.273 ha & 127.76 ha \\
\hline Housing units & 24,547 units & 479 units & 196,376 units & 3,832 units \\
\hline
\end{tabular}


the housing complexes and gated security have converted such developments into something like a bedroom community or a "black box" (isolated urban/social fabric). Residents of such housing developments not only buy houses, but they must be ready to live the "lifestyle" provided by that housing estate.

Fourth, all of the land-development programmes and private housing in the valley have benefitted local landowners and are serving the needs of upper-middle and high-income families (Figure 2). Although the Kuleswore housing project targeted low-income workers, senior government staff members were able to instead purchase the serviced land through numerous loopholes in the development process. There remains a significant percentage of vacant land even long after project completion ( $23 \%$ of the vacant plots at Gongabu 6 years after project completion) because the landowners continue to seek profits and have resold prepared plots many times without actually constructing housing just for the capital gains made through those transactions. The market value of the serviced land returned to the landowners has increased by as much as 300 to $600 \%$ (Karki, 2004).

Government agencies are providing electricity, telephone lines and water supply to the new planned areas. In contrast, the urban poor living in isolated areas must themselves manage the cost of access-road construction, septic tanks and dry wells, pumping water from the ground and so on. A few years ago, the cost of a private apartment was between NPR 600,000 and NPR 5,200,000 depending on the total area, location, style, materials used, quality of infrastructure and other facilities. In recent years, the prices have dramatically increased. For example, the cost of the Community Housing (TCH Tower III) at Panipokhari, Kathmandu, developed by Comfort Housing, ranges from NPR 5,900,000 to NPR 9,300,000 per flat and the price at Guna Colony (High Rise Apartments) in Sinamangal, Kathmandu ranges from NPR 3,400,000 $\left(79 \mathrm{~m}^{2}\right)$ to NPR 3,900,000 $\left(84 \mathrm{~m}^{2}\right)$ for a three-bedroom apartment. In a country where the per capita income is about $\$ 270$, these prices are far beyond the means of many Nepalese. The house price to income ratio for Kathmandu is 10.6 (i.e., the housing price is 10 times the annual income of the average household), so the one-fourth of the population of Kathmandu with a household income under NPR 6,000 cannot afford private housing.

In 1992, the Nepal Housing Development Finance Company began operation, and many financial institutions started providing loans to individuals for the purchase, construction and renovation of houses. At present in Nepal, there are 17 commercial banks, 58 finance companies and 14 development banks (Prarthana, 2004). They each provide a wide range of housing loans for individuals as well as developers with longterm repayment periods (Table 4 ). They offer little assistance to low-income groups, however, because these groups have nothing to deposit as a mortgage in the bank. The Nepal Housing and Merchant Finance Company Limited is providing housing loans for all income groups, offering individual loans of NPR 300,000 to NPR 500,000 with a payback period of 5 years. These loans are unavailable to the urban poor because they stipulate that a borrower's income should be three times that of the monthly repayments. Those loan amounts are sufficient only to build bathrooms at the present market values.

Table 4: Housing mortgage loans offered by various banks

\begin{tabular}{|c|c|c|c|c|c|c|c|c|}
\hline Name of bank & $\begin{array}{l}\text { Purpose } \\
\text { of loan }\end{array}$ & $\begin{array}{l}\text { No. of } \\
\text { loans }\end{array}$ & $\begin{array}{c}\text { Loan period } \\
\text { (yrs., minimum) }\end{array}$ & $\begin{array}{l}\text { Interest } \\
\text { rate }\end{array}$ & $\begin{array}{l}\text { Percent } \\
\text { financed }\end{array}$ & Guarantee & Loan type & Criteria \\
\hline Everest Bank & $\begin{array}{l}\text { Purchase/ } \\
\text { construction/ } \\
\text { renovation }\end{array}$ & 1,036 & 15 & $9-9.75 \%$ & $75 \%$ & $\begin{array}{c}\text { Collateral, } \\
\text { personal } \\
\text { guarantee }\end{array}$ & $\begin{array}{l}\text { Equal monthly } \\
\text { instalments } \\
\text { (EMI) }\end{array}$ & $\begin{array}{c}\text { Monthly earnings } \\
\text { should be twice } \\
\text { the EMI }\end{array}$ \\
\hline $\begin{array}{l}\text { Nepal Invest- } \\
\text { ment Bank }\end{array}$ & $\begin{array}{l}\text { Purchase/ } \\
\text { construction/ } \\
\text { renovation }\end{array}$ & 31 & 15 & $11.5 \%$ & $70 \%$ & $\begin{array}{c}\text { Collateral, } \\
\text { personal } \\
\text { guarantee }\end{array}$ & $\begin{array}{l}\text { Equal monthly } \\
\text { instalments } \\
\text { (EMI) }\end{array}$ & $\begin{array}{l}\text { Certificate of } \\
\text { salary showing } \\
\text { disposable } \\
\text { income of at } \\
\text { least } 25 \% \text { more } \\
\text { than EMl }\end{array}$ \\
\hline Kumari Bank & $\begin{array}{l}\text { Purchase/ } \\
\text { construction/ } \\
\text { renovation }\end{array}$ & 250 & 15 & $11 \%$ & $60 \%$ & $\begin{array}{c}\text { Collateral, } \\
\text { personal } \\
\text { guarantee }\end{array}$ & $\begin{array}{l}\text { Equal monthly } \\
\text { instalments } \\
\text { (EMI) }\end{array}$ & $\begin{array}{l}\text { Monthly earnings } \\
\text { should be twice } \\
\text { the EMI }\end{array}$ \\
\hline ACE Finance & $\begin{array}{c}\text { Purchase/ } \\
\text { construction/ } \\
\text { renovation }\end{array}$ & / & 20 & $\begin{array}{l}10.5- \\
11.5 \%\end{array}$ & $70 \%$ & $\begin{array}{c}\text { Collateral, } \\
\text { personal } \\
\text { guarantee }\end{array}$ & $\begin{array}{l}\text { Equal monthly } \\
\text { instalments } \\
\text { (EMI) }\end{array}$ & $\begin{array}{l}\text { Certificate of } \\
\text { salary }\end{array}$ \\
\hline $\begin{array}{l}\text { Development } \\
\text { Credit Bank Ltd. }\end{array}$ & $\begin{array}{l}\text { Purchase/ } \\
\text { construction/ } \\
\text { renovation }\end{array}$ & 35 & 15 & $\begin{array}{l}10.5- \\
11.5 \%\end{array}$ & Up to $90 \%$ & $\begin{array}{c}\text { Collateral, } \\
\text { personal } \\
\text { guarantee }\end{array}$ & $\begin{array}{l}\text { Equal monthly } \\
\text { instalments } \\
\text { (EMI) }\end{array}$ & $\begin{array}{c}\text { Certificate of } \\
\text { salary }\end{array}$ \\
\hline
\end{tabular}

Source: Prarthana (2004) 

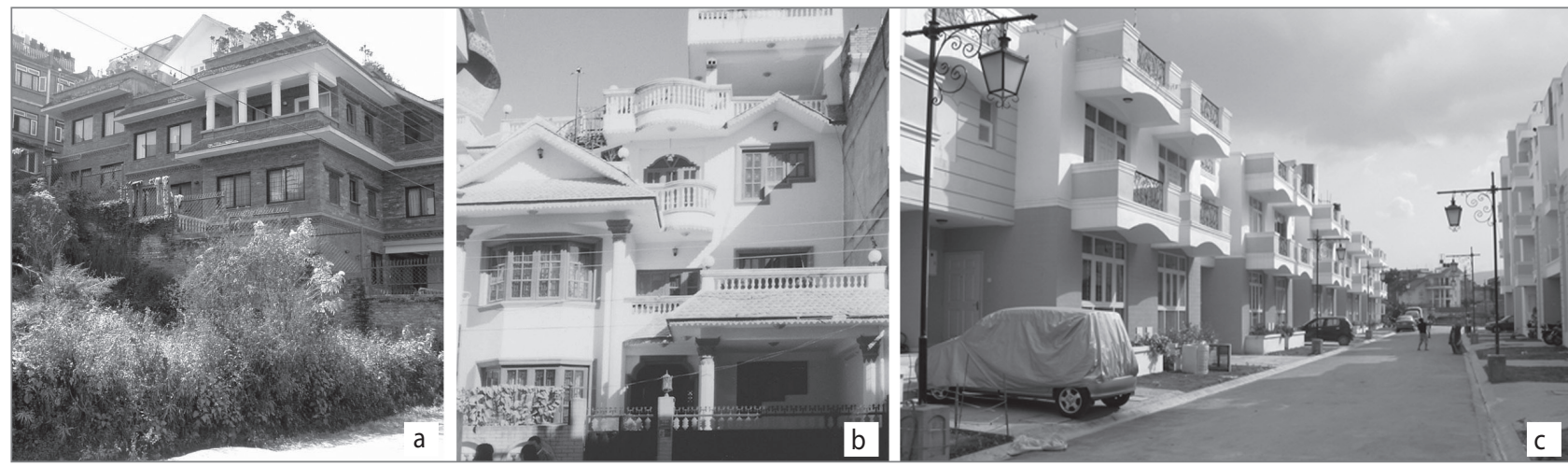

Figure 2: Planned developments that were meant only for high-income households: a) new bungalow at Kuleswore; b) bungalow at Gongabu; c) units at Sun Rise Home (photo: Bijaya K. Shrestha).

New high-rise apartments and other housing areas developed by many private companies have also created a new set of problems. A survey of tenants in some of these completed housing estates revealed that most of the occupants were from elite groups that had already purchased houses in the valley. For safety reasons, they rented their own homes and then moved to mass housing estates and apartments. Others bought those flats and housing units as a future investment. In fact, the housing industry has become a business venture for those that have money rather than a solution to the housing needs of the valley. In most cases, buyers receive ownership only of the flat and not of the land. In the event of an earthquake and structure collapse, none of the owners would be able to make a claim for the land. Most of these apartments lack social and emergency facilities. For example, if there were a fire on the 10th floor of the apartment block, rescue would be impossible because the fire-fighting equipment cannot shoot water higher than five stories up. The construction of high-rise, high-density apartments without consideration of the valley's capacity will create urban congestion and traffic jams, and put a tremendous strain on existing fragile infrastructures such as water supply and electricity. The development of expensive housing along with the construction of numerous commercial complexes and department stores in the valley has spatially divided the rich elite and urban poor (Kobayashi, 2006).

\section{Legal and institutional framework}

The provision of planned housing in the Kathmandu Valley should not be limited to land development and apartment construction but must be viewed within a broader framework of urban development and the urbanisation of the valley. In fact, there are several public agencies involved in housing management and urban development in Nepal. At the national and policy levels, the Ministry of Physical Planning and Works and the Department of Urban Development and Building Construction are responsible for formulating the necessary acts and policies to regulate housing and urban growth. The Town De- velopment Committees and municipalities implement these policies and programs at the local level. In addition, there are several agencies providing water, road construction and electricity and telephone lines, each of those services directly assisting in the development of urban areas. The Ministry of Local Development looks after the budgetary and administrative management of municipalities.

The government's three-part role - planning support, formulation of acts and policies, and implementation of housing and land-development projects - has been found to be inadequate. The absence of a national urbanisation policy, failure to regulate rapid urbanisation and lack of master development plans for the valley have constrained the impact of the public and private sectors' efforts towards housing provision. Only in the Seventh Development Plan (1985-1990) did the government for the first time acknowledge housing as one of the basic need components within the framework of social welfare through the establishment of the Ministry of Housing and Physical Planning in 1988 (now converted into the Ministry of Physical Planning and Works) and enactment of the new Town Development Act 1988 (His Majesty's Government, 1988). Until recently, the government had the tendency to view housing as a social problem rather than as a developmental activity that can have tremendous trickle-down effects for the economy.

Although the Town Development Act 1988 empowered the KVTDC to prepare planning standards and urban-design guidelines for housing and urban development, it has yet to do so even after two decades. The KVTDC and the local municipalities have the experience of implementing small-scale land developments, mainly for residential units. There are many planning elements lacking: an urban-design approach in the layout plans and construction of housing units, identification of the distinct features of each area and its surrounding context, the layout of well-defined, interconnected short streets and open spaces for multiple functions, some continuity of architectural style, the creation of socialisation and recreation spaces, and the building of community services in each neigh- 
bourhood. The myopic viewpoint of focusing on an individual site and then building on it can never create a healthy residential environment (Shrestha, 2007).

The local municipality (under the Ministry of Local Development) issues building permits, the KVTDC (under the Ministry of Physical Planning and Works) supervises the construction site and the Chief District Officer (under the Ministry of Home) punishes any defaulters. Poor managerial ability and little coordination among these agencies have promoted the building of non-engineered structures $(90 \%)$ and illegal constructions (27\%) in Kathmandu and Lalitpur (Central Bureau of Statistics, 1997). Even simple clauses of the bylaws such as restrictions regarding building height, floor projection or ground coverage are not enforced. Most of the high-rise apartments developed by private companies are neither regularly monitored for quality control nor have they incorporated any safety measures in the case of earthquakes or fire hazards.

In Nepal, no specific laws exist regarding landlord and tenant relations. An agreement between a landlord and a tenant is valid even if it is written upon an unregistered document. The tenancy law is inadequate, outdated and heavily in favour of landlords. In the absence of a regulatory mechanism, residents experience various tenancy-related hassles with landlords and neighbours. At times, they are required to pay unreasonable rents or accept unfair terms of tenancy without any legal basis. The recently enacted Apartment Act 2003 has facilitated the construction of high-rise apartment complexes in the valley with clauses regarding ownership transfer and the selling of housing units, but they lack clear provisions regarding construction quality and safety measures. The social problems of noise pollution and disturbance from neighbours as well as the timely maintenance of leakages and other defects are not clearly mentioned in the act. This is currently being carried out by resident committees.

The National Shelter Policy acknowledges that housing for the urban poor is a basic need of people and it links housing provision in poverty alleviation with the nation's economic development (Ministry of Housing and Physical Planning, 1996), but the government has yet to work out a specific plan of implementation. The inclusion of urban poor and homeless families is not possible in the land-pooling projects because of pressure from landowners for maximum returns in their land sales and the need to maintain self-sufficiency in the project financing. There is no legal basis for the participation of other agencies in the land-pooling projects. The Employee's Provident Fund (Nep. Karmachari Sanchaya Kosh) provides financial assistance to the government and the National Housing Development Finance Company, established in 1990, serves upper-middle and high-income groups. Other commercial banks and financial institutions have stringent requirements to obtain loans. The urban poor are thus isolated from the existing financial system. The cooperatives involved in funding programs to benefit the urban poor are primarily single non-government organisations (Lumanti Support Group for Shelter) and their activities are more focused on employment generation activities that target women living in squatter settlements. The government's role as a facilitator in housing development has made housing more inaccessible and unaffordable to the urban poor.

The Local Self-Governance Act 1999 (His Majesty's Government, 1999) has empowered the local municipalities to prepare, implement and monitor their own development plans within the municipality boundaries. Even after a decade, however, they have been unable to take on these responsibilities effectively. Most of the lands of the valley are privately owned, and the rest belongs to the central government. The opportunity to allocate some plots and housing units within the private-sector land areas through cross subsidising, incentives and building partnerships with local real estate companies has yet to be realised because of the lack of clear-cut policies, operational guidelines, and human resources within the municipalities. In terms of urban development, the Kathmandu Valley, encompassing less than $100 \mathrm{~km}^{2}$ of urban space, is a single spatial unit. There are, however, five different municipalities operating within the valley. Housing program collaboration and cooperation is sometimes difficult to achieve because the mayors belong to various political ideologies. The decision-making process and level of accountability in recent years have been hampered because of the absence of locally elected mayors in the municipalities due to political instability. At present, municipalities are more concerned with collecting revenue rather than regulating urban growth for sustainable development.

Despite all of this, efforts are being made at various levels to address the housing needs in the country through policy intervention. The national Urban Policy 2007, which acknowledges the informal sector as part of the urban economy and squatter settlements as a social problem, is in the process of being implemented. Financial support for large-scale capital improvement programs in the municipalities is channelled through the Town Development Fund. The Slum Upgrading Forum was established to forge greater alliance between various stakeholders, including financial donors. Municipalities are also engaged in numerous programs such as poverty mapping, rainwater harvesting and earthquake-risk reduction, implemented by the Department of Urban Development and Building Construction, United Nations Human Settlements Programme (UN-HABITAT) and United Nations Development Programme (UNDP). The Land Development Act and Real Estate Act are also now in the process of receiving government approval. 


\section{Conclusions and recommendations}

The huge demand for housing provision in the Kathmandu Valley is due to a combination of many factors including rapid urbanisation, haphazard urban growth and poor maintenance of housing in the centre and peripheral areas. The government's linear response since the 1970s through the implementation of land and housing developments, the creation of various policies and the establishment of new institutions including the involvement of the private sector have proved to be inadequate and ineffective. The land-pooling projects initiated in the 1980s are limited to small-scale land development. Landowners influence planning decisions due to a lack of planning guidelines for land-pooling projects and the minimal capabilities of the municipalities. All of the completed land-pooling projects were successful only in financing basic urban infrastructure and in benefitting the local landowners with little improvement in terms of the creation of a dynamic urban environment. The private sector implemented housing and apartment programs initiated since the early 2000s, with financial support from commercial banks, have become "gated communities" for the elite. In fact, serviced land and available housing units have become business ventures rather than social services or community developers. In this situation, the integration of both a "top down" and "bottom up" strategy is essential. At the central level, policy formulation aimed at linking housing development with urbanisation (and urban development) and the participation of various agencies and private sectors for comprehensive land development (including incorporation of the needs of the urban poor and the preparation of planning standards and urban design guidelines) is required. At the local implementation level, the municipality must be enabled to effectively manage resources, coordinate among various agencies, and monitor and supervise planning and development. The following strategic recommendations are suggested to solve the present housing deficit in the valley: (a)Regulate rapid urbanisation and haphazard urban growth through the formulation of a national urbanisation policy, identification of the valley's capacity, decentralisation of the valley's socioeconomic activities and the development of a master plan for the entire valley;

(b) Ensure the government's involvement in all aspects of housing development to increase the supply of affordable housing, maintain minimum housing standards and increase the availability of housing to the urban poor and low-income groups;

(c) Develop planning standards and urban-design guidelines to integrate land development and building construction for the creation of dynamic urban environments within the land-pooled areas and to create social and emergency services for the private housing developments. This will not only encourage the private sector's involvement but also break up the landowners' monopoly over providing amenities in those areas. In addition, ensure the setting aside of a certain percentage of developed land and housing units for the urban poor through the involvement of the concerned agencies, government subsidies and other similar measures;

(d)Formulate a housing bill to secure ownership rights and to make improvements and upgrade and regularise slum and squatter communities. Provide tax incentives for improving the existing housing in the valley;

(e) Promote micro-financing and other provisions to allow the urban poor access to financing for buying and improving their housing;

(f) Improve the capability of local municipalities for policy coordination with regional planning authorities and government agencies as well as for resource mobilisation, collaboration of funds and programs with local non-government organisations, community-based organisations and various donor agencies, and the monitoring of housing development during the implementation phase.

Bijaya K. Shrestha

S (settlement-society-sustainability) 3 Alliance, Development Forum for Habitat, Kathmandu, Nepal

E-mail: bkshrestha@hotmail.com

\section{References}

Adhikari, A. P. (1998) Urban environmental planning in Nepal: Analysis, policies and proposals. Kathmandu, The World Conservation Union.

Backe-Hansen, O. (1985) Project Kathmandu. Master's thesis. Trondheim, University of Trondheim, Norwegian Institute of Technology, Division of Town and Regional Planning.

Central Bureau of Statistics (1997) Nepal living standards survey report. Vols. I and II. Kathmandu.

Central Bureau of Statistics (2004) Nepal living standards survey report 2003/04. Vols. I and II. Kathmandu.

Cohen, D., Spear, S., Scribner, R., Kissinger, P., Mason, K. \& Wildgen, J. (2000) Broken windows and the risk of gonorrhea. American Journal of Public Health, 90(2), pp. 230-236. DOI: 10.2105/ AJPH.90.2.230

Child Workers in Nepal Concerned Centre (1999) Voice of child workers. CWIN's Quarterly Newsletter, 28, Nov.

Department of Urban Development and Building Construction (2003) Land pooling: What, why, where and how. Kathmandu.

Dunn, J. R. (2002) Housing and inequalities in health: A study of socioeconomic dimensions of housing and self reported health from a survey of Vancouver residents. Journal of Epidemiology Community Health, 56(9), pp. 671-682. DOI: 10.1136/jech.56.9.671

Dupuis, A. \& Thorns, D. C. (1998) Home, home ownership and the search for ontological security. The Sociological Review, 46(1), pp. 24-47. DOI: 10.1111/1467-954X.00088

Garnett, D., Reid, B. \& Riley, H. (1991) Housing finance. Coventry, Institute of Housing and Harlow, Longman. 
Halcrow Fox Associates et al. (1991) Kathmandu Valley urban development plans and programs: Strategy plan for Kathmandu Valley. Vol. I: Text. Kathmandu, Department of Housing and Urban Development, Ministry of Housing and Physical Planning.

His Majesty's Government (1973) Town Development Act 1973. Kathmandu.

His Majesty's Government (1988) Town Development Act 1988. Kathmandu.

His Majesty's Government (1999) Local Self-Governance Act 1999. Kathmandu.

Informal Sector Research and Study Centre (2004) District development profile of Nepal 2004. Kathmandu.

Joshi, J. (1999) Housing and urban development in Nepal. Kathmandu, Naveen Press.

Karki, T. K. (2004) Implementation experiences of land pooling projects in Kathmandu Valley. Habitat International, 28(1), pp. 67-88. DOI: 10.1016/S0197-3975(02)00085-1

Kathmandu Valley Town Development Committee (1999) Status of comparative project features. Kathmandu.

Kathmandu Valley Town Development Committee (2000) Development plan of Kathmandu Valley - 2000. Kathmandu.

Kathmandu Valley Town Development Committee (2002) Long term development concept of Kathmandu Valley. Kathmandu.

Kobayashi, M. (2006) Social change in Kathmandu related with globalisation and liberalisation - Potential of new life style and domestic market. Planning Journal of Tokyo University, 44(1), pp. 27-38.

Lumanti Support Group for Shelter (2003) A situational analysis of urban poor communities in Kathmandu and Lalitpur. Kathmandu.

Lumanti Support Group for Shelter and Nepal Water for Health (2000) The water supply and sanitation situation of the urban poor in the Kathmandu Valley: Results of a research study. Kathmandu.

Ministry of Housing and Physical Planning (1988) Guided land development, a proposed implementation methodology. Kathmandu.

Ministry of Housing and Physical Planning (1996) National shelter policy 1996. Kathmandu.

Ministry of Population and Environment (1999) Environmental planning and management of the Kathmandu Valley. Kathmandu.

National Habitat Committee Nepal (1996) National plan of action. Kathmandu.

National Planning Commission (2005) Summary of results on poverty analysis from Nepal living standards survey (2003-04). Kathmandu.

National Planning Commission (2002) The tenth plan 2002-2007. Kathmandu.

Prarthana, S. (2004) Is enabling enough? Housing finance for low income groups in Kathmandu, Nepal. Typescript.

Rabenau, B. (1990) Issues in housing development. Kathmandu, Urban Development Through Local Effort.

Regmi, D. N. \& Joshi, D. (1988) Existing sanitary conditions of the households in Kathmandu Valley. Kathmandu, Ministry of Health.
Research Triangle Institute (2001) Willingness to pay for improved water supply in the Kathmandu Valley. Kathmandu.

Shrestha, B. K. (2005) How not to design a neighbourhood - Reviewing different residential precincts of Kathmandu. SCITECH Nepal, A Journal of Scientific and Technical Studies, 8(2), pp. 46-69.

Shrestha, B. K. (2006) Land pooling system in the Kathmandu Valley - Successful in financing infrastructure but failure in achieving urban environment. SCITECH Nepal, A Journal of Scientific and Technical Studies, 9(3), pp. 7-19.

Shrestha, B. K. (2007) Planned residential neighbourhood development in Kathmandu Valley: Community building or provision of physical infrastructure? Protibesh: Environment, Journal of the Department of Architecture, 11, pp. 33-44.

Shrestha, S. \& Shrestha, B. K. (2009) The influence of water in shaping culture and modernization of the Kathmandu Valley. In: Feyen, J., Shannon, K. \& Neville, M. (eds.) Water \& urban development paradigms - Towards an integration of engineering, design and management approaches, pp. 183-188. London, CRC Press.

Tanaka, M. (1997) Conditions of low income settlements in Kathmandu: Action research in squatter settlements. Typescript.

Thapa, R. B. \& Murayama, Y. (2010) Drivers of urban growth in the Kathmandu Valley, Nepal: Examining the efficacy of the analytic hierarchy process. Applied Geography, 30(1), pp. 70-83. DOI: 10.1016/j.apgeog.2009.10.002

USAID (1994) Carpet relocation study. Kathmandu.

World Conservation Union (1995) Regulating growth: Kathmandu Valley. Kathmandu. 